\title{
TRUST EFFECT ON SINO-MONGOLIAN IJV PERFORMANCE
}

\author{
Enkhzaya Tengis \\ Postgraduate Student in Corporate Management, SILC Business School, Shanghai University, \\ Shanghai, China
}

Article DOI: https://doi.org/10.36713/epra9635

DOI No: 10.36713/epra9635 \begin{abstract}
scholars' attention. In many different cultures, especially in IJV, many scholars agreed that trust is an important factor in successful IJV. Most of international investments in Mongolia are from Chinese organizations. The purpose of this paper is to examine level of trust and its' impact on organization's performance in Sino-Mongolian IJV. Results show that trust does have impact on performance and Mongolian employees have lower level of trust compared to Chinese employees. Also results show that, people with experience in abroad have higher level of trust and performance satisfaction. Moreover, employees had higher level of trust, but managers had higher level of satisfaction in IJV performance. The findings of this paper will help future researchers and investors, and have provide implications and limitations for further research.

KEYWORDS: Trust, IJV, Performance, Sino-Mongolian, Effect;
\end{abstract}

For the last few years, the number of international joint ventures has been increasing and IJV success factors draw

\section{INTRODUCTION}

For the last three decades researchers has been paying lot more attention on international joint venture (IJV) and its' success key factors in financial and non-financial ways. Joint ventures are helpful for firms to reduce transaction cost, gain more access in technology and entering global markets. Therefore, trust is one of the key factors in successful IJV.

Trust has been studied from many different angles and perspectives, but in IJV field trust can be studied from inter-personal level, inter-organizational level and organizational level. Previous scholars recognized that higher the trust level in different cultural groups, higher the information exchange, and more enjoyable environment in workplace, which directly leads to better performance and employee engagement.

Compared to other countries China's investments and joint ventures take big place in Mongolia's market. Mongolian economy is dependent on foreign trade and mining. China accounts the most of the IJV's partners and almost 60 percent of foreign trade of Mongolia economy. More than 90 percent of Mongolian mining exports to China and more than one third of Mongolian imports are from China.

On the other hand, According to Khishigjargal (2018) Mongolians perceive China's foreign investment and activities in Mongolia as a threat in Mongolian economy independence and national identity. This leads Mongolian people to perceive Chinese investment and Chinese people in some kind of negative way. These perceptions may influence Mongolian partner's decision-making, which in turn influences Sino-Mongolian IJV investments and performance.

This papers aims to examine Mongolian people's trust level from inter-personal perspective and its impact on Sino-Mongolian IJV performance. Some variables like personal experience, workload, job position and home country are examined. The result will help to improve Sino-Mongolian IJV performance and provides more understandable information on importance of trust between local and foreign employees. Furthermore, it can be useful for foreign investors and enhance their IJV performance in Mongolia.

\section{LITERATURE REVIEW}

2. 1 Trust in IJV

IJV and its successful performance have been drawing great deal of researchers' attention lately. Foreign investors perceive international joint venture as a tool to enter global market. It is no secret that employees are soul of the company and assets. Many 
researchers suggest, performance of employee has positive impact on organization's performance and trust has been recognized as one of the important factor influencing it. Moreover, as Guar, Ma \& Ding (2018) suggested that by combining two or more companies it will improve their competencies and accomplish projects that cannot be accomplished by one self. Thus becoming a part of international joint venture can be good strategy for partners, it will insure their survival and increase competence.

Partner's home country has an impact on trust building between employees. Previous history and current economic relationship between partners' home country have significant effect on trust level between partners and employees (Gokhan, 2013). According to Xiaosong (2011), younger age employees more easily put trust on their coworkers and employee's communication skills played a big role in trust building. As Margreet and Peter (2003) examined in international joint venture trust is basically based on individual's perceived interest of the partner.

As the world becoming globalized, individual's communication and acceptance in different cultures are increasing (Chen, 2005). Yu and Chen (2008) suggested that general communication becomes more crucial when it comes to different culture and country. From another angle, Zhan and Chen (2013) examined that multi-cultural backgrounds tends to behave in different ways, based on difference in organizational culture and business practices, which may lead to misunderstanding between partners in international joint venture. And these differences in culture and misunderstanding may cause negative effect on development and level of trust building (Gulati \& Sytch, 2007). Even perceived trustworthiness of partners from different countries may differ. Since the home country is an salient category in international joint venture, home country is an another factor determining the trust in international joint venture.

\section{2 Performance of international joint} venture

Dozens of previous papers examining international joint venture has enhanced the understanding of IJV, but there is none appropriate concept and measurement of international joint venture performance. In international joint venture, the concept of measuring performance is an often argued issue (Reus \& Ritchie, 2004). In general, performance of international joint venture has been conceptualized as IJV survival, financial outcome, overall satisfaction and achievement of goals. However, these measures still have considerable disagreement about validity and reliability. Because some researchers use financial outcome and organization's survival as a key indicator for performance, on the other hand, some researchers use overall satisfaction and accomplishment of organization's goals as a key factor for performance.

Moreover, cultural differences on IJV performance has an negative effect on managerial approach, international joint venture managers should be careful for choosing appropriate management styles for multinational groups (Junying, Yingben,. Etc, 2020).

In this paper overall satisfaction concept used to investigate Sino-Mongolian joint venture performance. In number of studies international joint venture's performance measured by manager's evaluation on organizations overall performance (Kwon, 2008). Even though, this method often receives treats to validity because of sampling error, it is commonly used measurement for international joint venture performance. Also, each respondent's satisfaction might be perceived differently depending on each individual (Hong, Kim \& Barbara, 2009).

\section{Hypotheses}

In international joint venture trust is an independent social categorization, which builds through information exchange, communication and liable. This mainly means experience based trust in international joint venture is relevant. According to Gulati (1995), in international business, partners make contract based on specific experiences with another. Gulati defined trust as a factor that can only gain through time as a function between partners.

Moreover, in international joint venture partner companies see nationality as an important categorization in the context of collaboration. Home country of other partner is a strong category in international joint venture. From here Guiso (2009) studied trustworthiness perception among European countries. Result showed that lower perceived trustworthiness countries had less trade, less collaboration and less investments, showing that nationality perceived trustworthiness have important economic implications.

But according to Khishigjargal (2018) Mongolian people perceive Chinese investments and activities as threat in Mongolian economy independence and identity.

Based on these arguments above

Hypothesis 1: Nationality of employee has positive impact on other employees' trust level.

Trust among employees is one of the most important thriving workforces. If there is no trust in workplace there will be argument and questioning in any decision making, also disrespectful communication and stress will turn down employees' productivity and may have negative impact on IJV performance.

Nathalie \& Jordana (2016) studied students' life style and experience in abroad impacting their decision making process. Result showed that students' experience in abroad had big impact on their decision 
making and careers. Students' language learning and teaching, facing problem skill, cultural difference awareness led personal development in individual's identity. Benson (2012) also suggests experience in abroad has a direct positive impact on individual's competence, language level, emotional expression and intelligent emotion.

\section{Hypothesis 2: Trust level of employee with experience in abroad is higher.}

Workload balance is an important factor for employees. Overworked employees might lose their motivation, work engagement and facing difficulties completing their tasks. This will automatically lead to work related stress, poor mental focus, and poor communication among employees, these will directly affect mistakes and have negative impact on group project, decision making, information exchange and performance.

Henry and his colleagues (2020) studied the effect of workload fairness influencing employee engagement and performance. Their result shows that employees comparing their workload with colleagues significantly impacting their job satisfaction and communication. Those whit unbalanced workload employees showed poor performance and had an poor communication with colleagues.

\section{Hypothesis 3: Trust in workload balance has an positive effect on performance.}

Employees put trust on each other and evaluate their managers based on each individual's personal skills, not by their job position. According to Katarzyna and Dagmara (2012) employees think that their managers are supposed to protect them, and employee's trust level decreases when his/her job becomes more responsible.

Hypothesis 4: Employee's job position has direct impact on their trust level.

\section{METHODOLOGY}

\subsection{Data collection}

For data collection I used online survey method, and used SPSS software for analysis. Sino-Mongolian IJV company employees participated. Mongolia has become substantial recipients of foreign investment originating from a wide range of countries and IJVs are an important vehicle for foreign investors to enter. This allowed us to survey IJVs with partners and making our sample suitable to test our hypotheses.

For our paper data collection, I sent out 200 questionnaires to Sino-Mongolian IJV companies' managers and employees. 128 questionnaires were returned, but only 121 questionnaires contained sufficient information for our analysis. In addition, $60.9 \%$ of participants were Mongolian and $47.9 \%$ of participants were Chinese, also $52.1 \%$ of respondents were workers and $47.9 \%$ of respondents were managers.
The aim of this research is to study trust level of Sino-Mongolian international joint ventures employees and to test how trust is effecting its' performance. Hence, the most of Sino-Mongolian joint ventures in Mongolia are mining and petroleum companies.

\subsection{Companies}

The first company is PetroChina Daqing Tamsag LLC, which is extracting oil in the Tamsag area of Dornod province, Mongolia. The 100 percent Chinese owned PetroChina Daqing Tamsag LLC has a 20 years agreement to exploit hydrocarbon reserves in the Tamsag area, . Company has about 400 employees, 75 percent of the 300 employees are local Mongolian.

The second company is Dong Sheng Petroleum Mongolia LLC, which is extracting oil in Dornogobi province in Mongolia. The company has been working since 2001, and now has about 260 employees; most of the employees are Chinese.

\subsection{Measurements}

In this paper, Likert 5-item scale was used to capture the relationships between IJV variables. The respondents gave their answers according to their perceptions the degree. The scale items are listed in the Appendices. Then Spss21.00 software was used to calculate the results.

Home country: In this paper, appendix (1) is to measure the home country perceived trustworthiness. Main factors impacting trustworthiness are cultural difference, organizational and history of home country.

Personal experience: These variables are measured by description (1) and description (5) from Appendix 2. In addition, here used mainly two dimensions: the first one is personal experience working with foreigners and the second one is the time spent together by foreign and local employees, the similarity of value and work attitudes. Those dimensions can reflect the life styles and attitude of the different employees.

Unbalanced workload: The variables are measured by description (5) (see appendix 3).The workload distributive inequity will result anger in employees, which will cause poor communication in workplace and psychological unbalance in employees, therefore influencing trust level. Variables of communication are measured by description (1), description (2), and description (3) (see appendix 3). There are many factors conducing ineffective communication, such as language system, psychological issues, different communication styles and distance, etc. Thus description (4) and description (6) (see appendix 3) measured trust between local and foreign employees.

Job position: Degree of trust is measured by description in appendix 2 and appendix 3. During the research through previous literature, found some literatures compared manager-employee trust level, so 
in this paper i will test individual's job position impact on their trust level.

IJV Performance: Performance can be measured by how well the interests of the parents were satisfied. In survey, the respondents were asked to rate the degree to which their IJV had achieved these goals and each individuals satisfaction of their company performance on Likert scale (see appendix 4). The items were divided into financial and non-financial achievements.

\section{DATA ANALYSIS}

The results in table 1 shows coefficient of company trust is $0.449(>)$, which means company trust coefficient has positive impact on company performance. Also Mongolian and Chinese people's trust coefficient was 0.432 and 0.488 , both are greater than 0 , which means employees' trust has positive impact on company performance, and Chinese employees showed more outstanding trust coefficient. Moreover, compared to managers, employees' trust has greater positive impact on company performance.

Table 1: Regression coefficient of company trust and performance

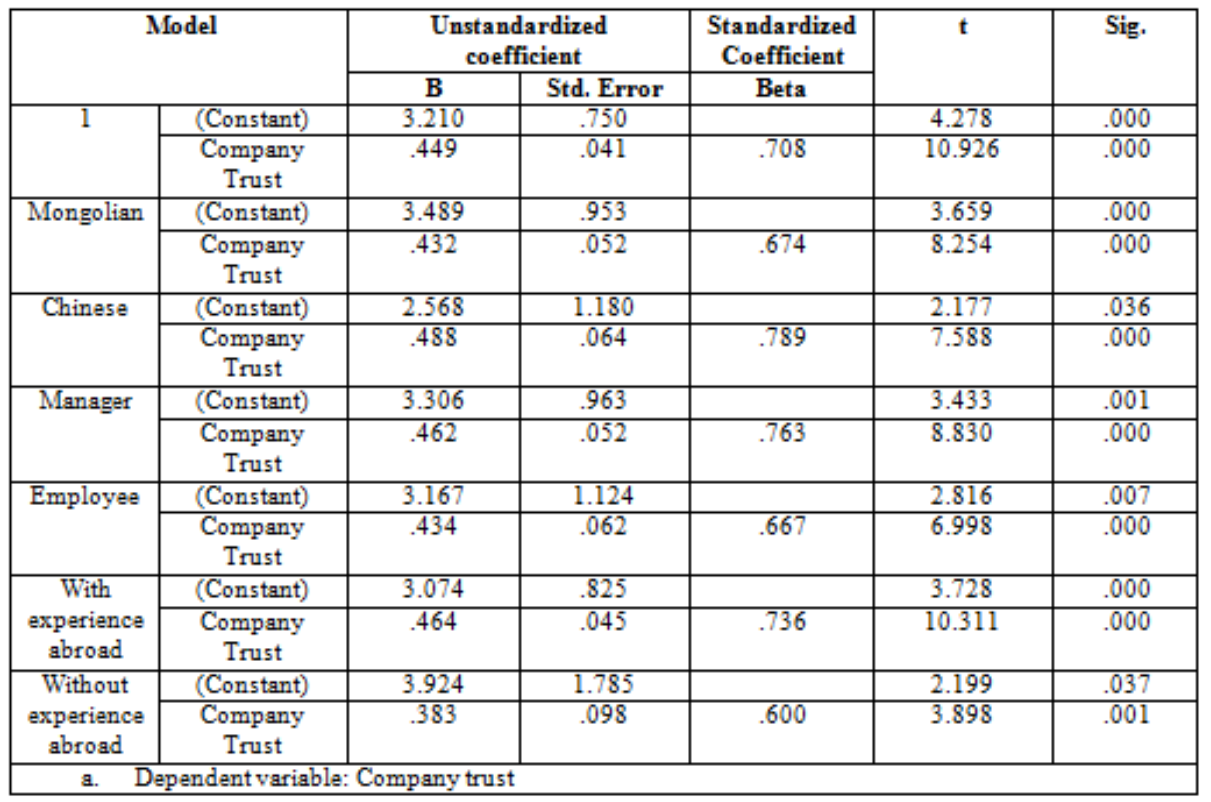

Result from table 2 shows employees with experience abroad average value was 11.80 , employees without experience abroad average value was 12.24, which means compared to employees without experience abroad; employees with experience abroad are easier to put trust.

Table 2: Statistics table of level of trust of people with and without experience in abroad

\begin{tabular}{|c|c|c|c|}
\hline \multicolumn{2}{|c|}{ Experience in abroad } & Statistics & $\begin{array}{c}\text { Standard } \\
\text { error }\end{array}$ \\
\hline With experience abroad & Average value & 11.80 & .563 \\
\hline Without experience abroad & Average value & 12.24 & .783 \\
\hline Mongolians with experience abroad & Average value & 11.67 & .745 \\
\hline $\begin{array}{c}\text { Mongolians without experience } \\
\text { abroad }\end{array}$ & Average value & 12.24 & .783 \\
\hline Managers with experience abroad & Average value & 11.81 & .783 \\
\hline $\begin{array}{c}\text { Managers without experience } \\
\text { abroad }\end{array}$ & Average value & 13.20 & 1.405 \\
\hline Employees with experience abroad & Average value & 11.8 & .819 \\
\hline $\begin{array}{c}\text { Employees without experience } \\
\text { abroad }\end{array}$ & Average value & 11.74 & .945 \\
\hline
\end{tabular}


The result from table 3 shows employees trust coefficient is $0.495>(0)$, which means employee trust level has positive impact on performance. Also, Mongolian and Chinese employees' coefficient number was 0.489 and 0.512 , meaning that compared to Chinese people, Mongolian people have lower level of trust and satisfaction. In addition, coefficient number of employees with experience in abroad was 0.513 and coefficient number of employees without experience in abroad was 0.415 , which is meaning that employees with experience in abroad have higher level of trust and satisfaction.

Table 3: Regression coefficient of employee trust and performance

\begin{tabular}{|c|c|c|c|c|c|c|}
\hline \multirow{2}{*}{\multicolumn{2}{|c|}{ Model }} & \multicolumn{2}{|c|}{$\begin{array}{l}\text { Unstandardized } \\
\text { coefficient }\end{array}$} & \multirow{3}{*}{$\begin{array}{c}\begin{array}{c}\text { Standardized } \\
\text { Coefficient }\end{array} \\
\text { Beta } \\
\end{array}$} & \multirow[b]{3}{*}{-.127} & \multirow[t]{2}{*}{ Sig. } \\
\hline & & B & Std. Error & & & \\
\hline \multirow[b]{2}{*}{1} & (Constant) & -.086 & .680 & & & .899 \\
\hline & $\begin{array}{c}\text { Employee } \\
\text { Trust }\end{array}$ & .495 & .029 & .840 & 16.892 & .000 \\
\hline \multirow[b]{2}{*}{ Mongolian } & (Constant) & -.011 & .861 & & -.013 & .990 \\
\hline & $\begin{array}{c}\text { Employee } \\
\text { Trust }\end{array}$ & .489 & .037 & .825 & 13.125 & .000 \\
\hline \multirow[b]{2}{*}{ Chinese } & (Constant) & -.298 & 1.082 & & -.275 & .785 \\
\hline & $\begin{array}{c}\text { Employee } \\
\text { Trust }\end{array}$ & .512 & .047 & .879 & 10.902 & .000 \\
\hline \multirow[b]{2}{*}{ Manager } & (Constant) & .212 &, 731 & & .290 & .773 \\
\hline & $\begin{array}{c}\text { Employee } \\
\text { Trust }\end{array}$ & .497 & .031 & .905 & 15.875 & .000 \\
\hline \multirow[b]{2}{*}{ Employee } & (Constant) & -.301 & 1.105 & & -.273 & .786 \\
\hline & $\begin{array}{c}\text { Employee } \\
\text { Trust }\end{array}$ & .491 & .048 & .795 & 10.250 & .000 \\
\hline \multirow{2}{*}{$\begin{array}{c}\text { With } \\
\text { experience } \\
\text { abroad }\end{array}$} & (Constant) & -.401 & .706 & & -.569 & .571 \\
\hline & $\begin{array}{c}\text { Employee } \\
\text { Trust }\end{array}$ & .513 & .030 & .873 & 16.961 & .000 \\
\hline \multirow{2}{*}{$\begin{array}{l}\text { Without } \\
\text { experience } \\
\text { abroad }\end{array}$} & (Constant) & 1.390 & 1.828 & & .760 & .454 \\
\hline & $\begin{array}{l}\text { Employee } \\
\text { Trust }\end{array}$ & .415 & .080 & .707 & 5.194 & .000 \\
\hline
\end{tabular}

The result of table 4 shows that managers' level of trust is 12.05 and employees' level of trust is 11.78 , which means employees more easily put trust. Also Mongolian managers and employees have similar level of trust, but Chinese employees have higher level of trust compared to managers. Moreover, managers and employees who have experience in abroad did not have any difference in their level of trust, but on the other hand people without experience in abroad have slightly different level of trust, for example employees without experience in abroad had highest level of trust.

Table 4: Statistics table of level of trust of people with different job position

\begin{tabular}{|c|c|c|c|}
\hline \multicolumn{2}{|c|}{ Job position } & Statistics & $\begin{array}{c}\text { Standard } \\
\text { error }\end{array}$ \\
\hline Managers & Average value & 12.05 & .691 \\
\hline Employees & Average value & 11.78 & .635 \\
\hline Mongolian managers & Average value & 11.85 & .869 \\
\hline Mongolian employees & Average value & 11.88 & .729 \\
\hline Chinese managers & Average value & 12.33 & 1.146 \\
\hline Chinese employees & Average value & 11.38 & 1.313 \\
\hline Managers with experience in abroad & Average value & 11.81 & .783 \\
\hline $\begin{array}{c}\text { Employees with experience in } \\
\text { abroad }\end{array}$ & Average value & 11.80 & .819 \\
\hline $\begin{array}{c}\text { Managers without experience in } \\
\text { abroad }\end{array}$ & Average value & 13.20 & 1.405 \\
\hline $\begin{array}{c}\text { Employees without experience in } \\
\text { abroad }\end{array}$ & Average value & 11.74 & .945 \\
\hline
\end{tabular}




\section{DISCUSSION}

Home country: Based on a data above hypothesis 1 is supported.

Here conclude that Chinese people are more likely to show inter-organizational trust than Mongolian people. Also employees tend to hold higher level of trust to their colleagues than managers. Mongolian people are more aware of home country of their IJV colleagues, and showed lower level of trust than Chinese people.

Experience in abroad: Based on the data above, hypothesis 2 is supported and here conclude that trust level of workers with experience in abroad and workers without experience in abroad were similar. And managers with experience in abroad possess higher trust than managers without experience in abroad.

Unbalanced workload: Based on the data above, hypothesis 3 is supported and there exists no direct relationship between unbalanced workload and satisfaction.

Job position: Based on the data above, hypothesis 4 is supported and here conclude that Chinese managers showed less trust than Chinese employees, while Mongolian managers and workers showed similar trust level.

\section{CONCLUSION}

In this paper to investigate trust and its' effect on company performance, I did a survey from SinoMongolian international joint venture employees and gave an empirical evidence supporting hypotheses. The conclusions of this paper contributes empirical explanations to a relationship between trust and organization's performance, also our empirical evidence shows that certain variables do have an impact on level of trust in international joint venture. Here are the summarized main results are shown down below:

1. People with experience in abroad have higher level of trust and performance satisfaction.

2. Mongolian people have lower level of trust, and Mongolian managers and employees did not have significant difference in their IJV performance satisfaction.

3. Chinese employees have higher level of trust than Chinese managers.

4. Managers have higher level of IJV performance satisfaction than employees.

The findings of this paper provide useful information for international investors. For the future research hoping to build trust among Mongolian employees some implications have suggested.

First of all, IJV companies should encourage their employees by multiple activities, those activities should increase employees communication and level of trust.
Second, pay proper attention on each employees' workload balance, balanced workload should improve employees psychology and decrease their work related stress.

Third, available public information exchanging area in office, where employees can spend some time together and talk about not work related topics. For example: resting corner, lunch table and foosball table etc.

The last implication is to encourage and support employees to go on international business trip or something, this will improve their personal understanding and acceptance toward different cultures.

While the conclusions and results helping to understand Sino-Mongolian IJV level of trust and performance, few limitations have suggested for further research.

First, strive for larger data sampling. This paper' survey respondents are petroleum company employees, who live together on camp, which might have an impact on their trust level. Different field IJV employees trust level result might be differentiate.

Second, data sampling method. This paper used online survey sampling method, but conducting an interview might have different result.

The last limitation is to use different variables. Using different variable to examine the results might end up with different results.

\section{REFERENCE}

1. Abdel-Hamid (2012). Influence of individual, lifestyle and work-related factors on the work ability among office workers. Egyptian Journal of Occupational Medicine, 2012; 36 (1) : 1-13

2. Bates C. A methodology study of Hersey and Blanchard situational leadership theory. Int $J A d v$ Eng Technol Manage Appl Sci 2016; 3(11): 42-48.

3. Berg ME and Karlsen JT. A study of coaching leadership style practice in projects. Manage Res Rev 2016; 39(9): 1122-1142.

4. Blanchard KH. Situational leadership. Adapt your style to their development level. Leadersh Excell 2008; 25(5): 19.

5. Calantone, Roger J. and Yushan Sam Zhao (2000), "Joint Ventures in China: A Comparative Study of Japanese, Korean, and U.S. Partners,” Journal of International Marketing, 10 (4), 53-77.

6. Clifton N, Huggins $R$, Morgan B, et al. An appropriate tool for entrepreneurial learning in SMEs? The case of the 20Twenty Leadership Programme. Local Econ 2015; 30(5): 534-556.

7. Dunne TC, Aaron JR, McDowell WC, et al. The impact of leadership on small business innovativeness. J Bus Res 2016; 69(11): 48764881.

8. Dyer. H. J and Chu. W (2003). The Role of Trustworthiness in Reducing Transaction Costs and Improving Performance: Empirical Evidence from the United States, Japan, and Korea. Organization Science 14(1):57-68. 
9. Gachingiri A. Effect of leadership style on organizational performance: a case study of the United Nations Environment Programme (UNEP), Kenya. Int Acad J Innov Leadership Entrepreneurship 2015; 1(5): 19-36.

10. Henry Inegbedion, $a$, * Emmanuel Inegbedion, $b$ Adeshola Peter, a and Lydia Harrya. Perception of workload balance and employee job satisfaction in work organisations, doi: 10.1016/j.heliyon.2020.e03160

11. Hofstede, G. (2001), Culture's consequences: comparing values, behaviors, institutions, and organizations across nations, Sage Publications, 2nd Edition p. 596.

12. Jesmin Islam and $\mathrm{Hui} \mathrm{Hu}, 2012$. A review of literature on contingency theory in managerial accounting. African Journal of Business Management Vol. 6(15), pp. 5159-5164.

13. Katarzyna Krot1 and Dagmara Lewicka (2012). The importance of trust in manager-employee relationships. International Journal of Electronic Business Management, Vol. 10, No. 3, pp. 224-233.

14. Khishigjargal Enkhbayar (2018). Public perception on Chinese investment in Mongolia: An exploratory study. Tsinghua. Tsinghua university management school master's degree diplom.

15. Kogut, B. (1988), "Joint ventures: theoretical and empirical perspectives", Strategic Management Journal, Vol. 9, pp. 319-332.

16. Krishnan Rekha, Martin Xavier and Noorderhaven Niels (2006). When does trust matter to alliance performance? The Academy of Management Journal 49(5):894-917, DOI: 10.5465/AMJ.2006.22798171.
17. Martin Pfieffer and James E. Cote (1991). Inglehart's Silent Revolution Thesis: An Examination of Life-Cycle Effects in the Acquisition of Postmaterialist Values. Social Behavior and Personality An International Journal 19(4):223-235, DOI: 10.2224/sbp.1991.19.4.223.

18. Masoodul Hassan, Nilüfer V. Toylan, Fatih Semerciöz and Ibrahim Aksel, 2012. Interpersonal Trust and Its Role in Organizations. International Business Research; Vol. 5, No. 8;

19. McEvily Bill, Perrone Vincenzo and Zaheer Aks (2003). Free to be trusted? Organizational constraints on trust at the boundaries. Organization Science, 14 (4), 422-439.

20. Ranjay Gulati and Maxim Sytch, 2007. Dependence Asymmetry and Joint Dependence in Interorganizational Relationships: Effects of Embeddedness on a Manufacturer's Performance in Procurement Relationships. Administrative Science Quarterly 52(1):32-69.

21. Wang, K. Y. and Fulop, L.(2007), "Managerial trust and work values within the context of international joint ventures in China", Journal of International Management, Vol.13, pp.164-186.

22. Yan, A. and B. Gray (1994), "Bargaining Power, Management Control, and Performance in the United States-China Joint Ventures: A Comparative Case Study," Academy of Management Journal, 37 (6), 1478-1517.

23. Zaheer Srilata (2006). Trust across borders. Journal of International Business Studies 37(1):2129, DOI: 10.1057/palgrave.jibs.8400180.

24. Zheng $X$. Song (2011). The effect of trust on international joint venture performance in China. Journal of economic behavior. 1 (1), 79-96.

\section{Demographic data}

Nationality

Job position

Do you have experience in abroad?

Appendix 1: The measurement of home country affecting trust among parents.

Do you agree or disagree with the following statements? ( Please use a 5-point scale where 1 is Strongly Agree and 5 is Strongly Disagree).

a. The other parent will stick to the contract even if it may cost them.

b. The other parent will not violate the promises they made in contract even if it would be beneficial.

c. The history between parents' home country and religion difference does not impact the relationship between them.

d. Current government relationship of parents' home country does not impact the relationship between them.

e. Home country of other parent has big impact on local parent's trustworthiness.

Appendix 2: Measurement of trust of personal view.

Do you agree or disagree with the following statements? ( Please use a 5-point scale where 1 is Strongly Agree and 5 is Strongly Disagree).

a. My experience in abroad helped me to understand and accept cultural differences.

b. If I need help in workplace, I would prefer foreign colleagues.

c. I trust my colleagues by their personal honesty but not by their nationality.

d. I don't have any difficulties to work as a group with my foreign colleagues.

e. I trust my foreign colleagues who can speak and understand my language and culture than who cannot. 
Appendix 3: Measurement of trust between employees

Do you agree or disagree with the following statements? ( Please use a 5-point scale where 1 is Strongly Agree and 5 is Strongly Disagree).

a. I enjoy chatting with my foreign colleagues on our rest time.

b. I only talk do work related talk with my foreign colleagues.

c. Our local and foreign colleagues invite each other to their personal events (such as birthday party, dinner party etc...) outside work.

d. My foreign colleagues can be honest when there is a mistake on our work.

e. My foreign and local colleagues share workloads equally.

f. My relation with local colleagues is better than my relation with foreign colleagues.

Appendix 4: Measurement of performance

Do you agree or disagree with the following statements? ( Please use a 5-point scale where 1 is Strongly Agree and 5 is Strongly Disagree).

a. Our company always achieves our scheduled works.

b. Our company income is increasing.

c. I think my company is one successfully growing company. 